\title{
Transcriptome Analyses for the Anti-Adipogenic Mechanism of an Herbal Composition
}

\author{
Haeyong Lee, Ryunhwa Kang, Sungmin Bae, Soo Ahn Chae', Jung Ju Lee', Dong-Jin Oh²,
} Sukwon Park, Soo Hyun $\mathrm{Cho}^{4}$, Yae Jie Shim ${ }^{5}$ and Yoosik Yoon*

Department of Microbiology, ${ }^{1}$ Pediatrics, ${ }^{2}$ Internal Medicine, ${ }^{3}$ Radiation Oncology, ${ }^{4}$ Family Medicine, Chung-Ang University College of Medicine, Seoul 156-756, Korea, ${ }^{5}$ Departement of General Education, Seoul Women's University, Seoul 139-774, Korea

Received March 30, 2010 /Accepted April 26, 2010

\begin{abstract}
SH21B is a natural composition composed of seven herbs: Scutellaria baicalensis Georgi, Prunus armeniaca Maxim, Ephedra sinica Stapf, Acorus gramineus Soland, Typha orientalis Presl, Polygala tenuifolia Willd and Nelumbo nucifera Gaertner (Ratio 3:3:3:3:3:2:2). In our previous study, we reported that SH21B inhibited adipogenesis and fat accumulation in 3T3-L1 cells through modulation of various regulators in the adipogenesis pathway. The aim of this study was to analyze the transcriptome profiles for the anti-adipogenic effects of SH21B in 3T3-L1 cells. Total RNAs from SH21B-treated 3T3-L1 cells were reverse-transcribed into cDNAs and hybridized to Affymetrix Mouse Gene 1.0 ST array. From microarray analyses, we identified 2,568 genes of which expressions were changed more than two-fold by $\mathrm{SH} 21 \mathrm{~B}$, and the clustering analyses of these genes resulted in 9 clusters. Three clusters among the 9 showed down-regulation by SH21B (cluster 4, cluster 6 and cluster 9), and two clusters showed up-regulation by SH21B (cluster 7 and cluster 8) during the adipogenesis of 3T3-L1 cells. It was found that many genes related to cell proliferation and adipogenesis were included in these clusters. Clusters 4,6 and 9 included genes which were related with adipogenesis induction and cell cycle arrest. Clusters 7 and 8 included genes related to cell proliferation as well as adipogenesis inhibition. These results suggest that the mechanisms of the anti-adipogenic effects of SH21B may be the modulation of genes involved in cell proliferation and adipogenesis.
\end{abstract}

Key words : SH21B, adipogenesis, microarray, transcriptome

\section{서 론}

지방조직은 과잉 된 에너지를 저장하고 대사를 조절하는 등 생체의 중요한 기관이다. 지방조직의 이상은 지방세포의 에너지를 저장 및 지질 형성 기능을 손상시킴으로써 인슐린저 항성과 당뇨 등의 이상 증상을 유발한다[23]. 지방세포형성 (adipogenesis)은 세포 형태의 변화, 호르몬 민감성의 변화, 유 전자 발현의 변화 그리고 단백질 발현의 변화가 복합적으로 작용하면서 일어나는 특이적인 과정이다. 이러한 지방세포형 성의 유도는 CCAAT/enhancer-binding proteins (C/EBPs)와 peroxidase proliferator-activated receptor- $\gamma$ (PPAR $\gamma$ )라는 주요 전사인자들에 의해 조절된다 $[8,28]$. 여러 호르몬들과 세 포분화 유도물질 등에 의해 분화가 시작되면 $\mathrm{C} / \mathrm{EBP} \beta$ 와 $\mathrm{C} / \mathrm{EBP} \delta$ 를 포함한 초기 지방세포형성 조절자(adipogenic regulator)들이 발현되면서 후기 분화를 유도한다. $\mathrm{C} / \mathrm{EBP} \beta$ 와 $\mathrm{C} / \mathrm{EBP} \delta$ 에 의해 발현되는 $\mathrm{C} / \mathrm{EBPa}$ 와 $\mathrm{PPAR} \gamma$ 는 후기 분화에 서 adiponectin (ADIPOQ), lipoprotein lipase (LPL) 및 fatty acid binding protein4 (FABP4)와 같은 최종마커(terminal marker)들의 발현을 증가시킨다[24].

*Corresponding author

Tel : +82-2-820-5767, Fax : +82-2-820-5767

E-mail : thanks@cau.ac.kr
수 만개의 유전자 발현을 분석할 수 있는 cDNA/oligonucleotide microarray 기술은 생명과학을 비롯한 여러 학문에서 널리 사용되고 있다[21]. 이러한 microarray 기술은 3T3-L1 세 포를 이용한 지방세포형성 연구에도 적용되었는데, 수백 혹은 수천 개의 유전자들의 발현 변화가 유의적으로 지방세포형성 에 관여함이 여러 그룹들에 의해 밝혀졌다[14]. Microarray 실 험의 초기 데이터가 수집되면, 표준화 작업을 거친 후 유의 유전자(DEG, Differentially Expressed Gene) 분석, 유전자 정 보(GO, Gene Ontology) 분석, 신호전달(pathway) 분석 그리 고 군집(clustering) 분석 등의 다양한 분석을 통해 유효한 정 보로 전환된다.

$\mathrm{SH} 21 \mathrm{~B}$ 는 황금(Scutellaria baicalensis Georgi), 행인(Prunus armeniaca Maxim), 마황(Ephedra sinica Stapf), 석창포(Acorus gramineus Soland), 포황(Typha orientalis Presl), 원지(Polygala tenuifolia Willd), 하엽(Nelumbo nucifera Gaertner)의 혼합(비율 3:3:3:3:3:2:2)으로 이루어진 생약복합물로 한의학에서 비만의 치료에 사용되어 왔으나 그 분자적 메커니즘은 거의 연구되어 있지 않다. 최근 본 연구진에 의해 이루어진 선행연구의 결과 SH21B는 3T3-L1세포 및 고지방식이 마우스 동물모델에서 지 방세포형성 관련 유전자 발현 조절 및 지방축적 억제효과가 있음이 규명되었다[18]. 이번 연구에서는 microarray 분석을 이용하여 지방세포 분화 시 $\mathrm{SH} 21 \mathrm{~B}$ 에 의해 변화되는 유전자들 
의 발현 변화를 살펴보고 군집 분석을 통해 유전자 발현 변화 의 양상을 분석하였다.

\section{재료 및 방법}

\section{$\mathrm{SH} 21 \mathrm{~B}$ 의 제조 및 표준화}

$\mathrm{SH} 21 \mathrm{~B}$ 의 제조 및 표준화 과정은 선행 연구논문에서 상세하 게 제시되었으며 이를 요약하면 다음과 같다[18]. 원재료가 되 는 생약은 구주제약(Hwasung, Korea)에서 구입하였다. 황금, 행인, 마황, 석창포, 포황, 원지, 하엽의 7 가지 생약을 3:3:3:3:3:2:2의 비율로 혼합하여 $30 \%$ 에탄올에서 3시간씩 2회 추출한 후, 에탄올과 동일한 부피의 부탄올을 가하여 2시간 동안 추출한 다음 부탄올 층을 따로 분획하였다. 이후 부탄올 분획물을 증발농축기를 이용하여 용매를 증발시키고 분말상 태인 SH21B엑스를 얻었다. 최종적으로 얻어진 SH21B엑스의 양은 추출 전 생약 원료 양의 $4.9 \%$ 였다 $(\mathrm{w} / \mathrm{w})$. SH21B의 추출 후, thin layer chromatography를 사용하여 7종류의 생약 물질 의 성분을 조사하고 high performance liquid chromatography를 사용하여 구성 물질의 양을 측정한 결과, $11.4 \%$ 와 $4.2 \%$ 를 각각 차지하는 바이칼린(baicalin)과 아미그달린 (amygdalin)이 SH21B의 주요 성분으로 분석되었다.

\section{세포 배양 및 시약}

실험에 사용된 3T3-L1 세포(preadipocyte)는 ATCC (American type culture collection, Manassas, VA, USA)에서 구입하여 Dulbecco's modified Eagle's medium (DMEM)에 $10 \%$ calf serum, $100 \mu \mathrm{g} / \mathrm{ml}$ streptomycin, and 100 units $/ \mathrm{ml}$ penicillin 과 함께 $37^{\circ} \mathrm{C}, 5 \% \mathrm{CO}_{2}$ 세포 배양기에서 배양하였다. 다른 시약들은 Sigma Chemical Co. (St. Louis, MO, USA)에서 구입하였다.

\section{Adipogenesis 유도}

3T3-L1 세포는 phosphate buffered saline (PBS) 용액으로 씻어준 후, $1 \sim 2 \times 10^{5}$ cells $/ \mathrm{ml}$ 을 6 well-plate에 세포밀도가 $100 \%$ 가 될 때까지 배양하였다. 2 일 후(on day 0), $10 \%$ fetal bovine serum (FBS)을 포함한 DMEM에 $1 \mu \mathrm{g} / \mathrm{mL}$ insulin, $0.25 \mu \mathrm{M}$ dexamethasone 그리고 $0.5 \mathrm{mM}$ 3-isobutyl-1-methylxanthine이 첨가된 differentiation-induction medium (분화 유도 배지)로 교체하여 48 시간 처리하였다. 그 후 2일 간격으 로 $10 \% \mathrm{FBS}$ 를 포함한 새 배지에 $1 \mathrm{\mu g} / \mathrm{mL}$ insulin이 첨가된 differentiation-maintenance medium (분화 유지 배지)로 교 체되었다. Adipogenesis의 진행과정에서 $\mathrm{SH} 21 \mathrm{~B}$ 의 효능을 확 인하기 위해, 분화 유도 배지와 분화 유지 배지를 첨가할 때 $\mathrm{SH} 21 \mathrm{~B}$ 를 함께 처리하였다.

Total RNA 추출

Total RNA는 acid-phenol 추출법을 이용한 RNeasy kit
(Qiagen, Hilden, Germany)를 사용하여 제시된 편람에 따라 분리 정제되었다. 추출된 total RNA는 분광광도계를 이용하 여 optical density $(\mathrm{OD})$ 값을 측정하고 역전사(reverse transcription) 반응을 진행할 때까지 $-80^{\circ} \mathrm{C}$ 에 보관하였다.

\section{Microarray 분석}

$300 \mathrm{ng}$ 의 total RNA는 cDNA로 역전사하고 GeneChip IVT laveling kit (Affymetrix, Santa Clara, CA, USA)를 사용하여 표기되었다. 표기된 cDNA는 35,557 개의 유전자를 인지할 수 있는 probe들이 포함된 Mouse Gene $1.0 \mathrm{ST}$ array와 $45^{\circ} \mathrm{C}$ 에서 17시간 동안 보합결합 된 후, GeneChip Fluidics Station 450 (Affymetrix, Santa Clara, CA, USA)을 사용하여 $25^{\circ} \mathrm{C}$ 에서 non-stringent wash buffer로 세척되었다. 세척 후, Streptavidinphycoerythrin reagents로 염색과정을 거친 microarray는 GeneChip scanner 3000 (Affymetrix, Santa Clara, CA, USA) 을 이용하여 스케닝 하였다. GeneChip Operating Software (Affymetrix, Santa Clara, CA, USA)를 이용하여 측정되고 수 치화된 형광 발현 정도는 RMA-sketch 알고리즘을 통해 M-A plot을 측정하여 표준화하였다. 표준화 작업에는 Expression Console 1.0 (Affymetrix, Santa Clara, CA, USA) 프로그램이 사용되었다. 표준화된 값들을 이용한 fold change 분석, 통계 적 유의성 분석(t-test) 및 군집분석(clustering analysis)은 GenPlex software (Affymetrix, Santa Clara, CA, USA)을 이용 하여 수행되었고, 유전자들의 기능 분석은 GO Miner 를 이용 하여 수행되었다[36].

\section{결 과}

\section{Microarray 초기 분석}

SH21B가 유도하는 지방세포형성 억제(anti-adipogenesis) 에 대한 연구는 이미 본 연구진의 선행 논문에서 상세히 규명 된 바 있다[18]. 선행 연구에서 진행된 대로 3T3-L1 전지방세포 에 지방세포형성 유도물질을 첨가하여 충분히 분화를 유도했 을 때, 세포질 내에 지질 방울(lipid droplet)이 형성되는 것을 이번 연구에서도 동일하게 확인 할 수 있었다. 또한 SH21B의 첨가가 세포 내 지질 축적을 현저히 저해함도 확인되었다. 전 지방세포(on day 0), 7일간 분화된 세포(on day 7) 그리고 7일 간 분화 유도 시 $\mathrm{SH} 21 \mathrm{~B}$ 가 첨가된 세포(on day $7+\mathrm{SH} 21 \mathrm{~B}$ )에서 의 전체 유전자 발현 변화를 분석하기 위하여 microarray 분석 을 진행하였다. 세 종류의 시료에 대하여 total RNA를 정제하 고 $\mathrm{cDNA}$ 로 역전사 후 표식화 작업을 진행하였다. 그 후, Affymetrix Mouse Gene 1.0 ST array에 시료들을 적용하여 분석을 수행하였다. Microarray 결과는 보정(normalization) 을 진행하여 실험에 사용된 재료 및 시약의 특성 등에 따른 각종 변이 등에 의한 오차를 최소한으로 줄였다(Fig. 1). 보정 된 유전자 발현 결과는 각 시료 간에 비교 분석 후, 2 배 이상 
(A)

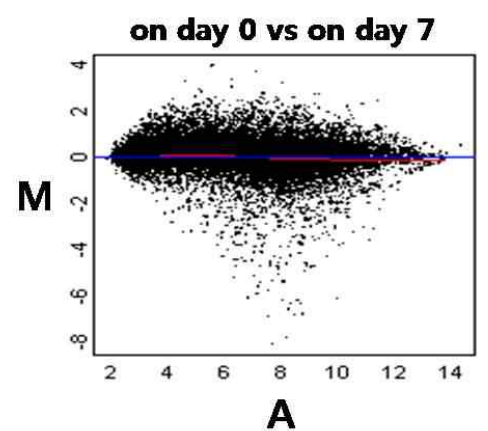

(B)

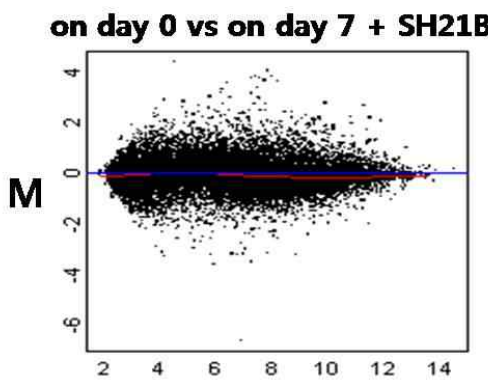

A
(C)

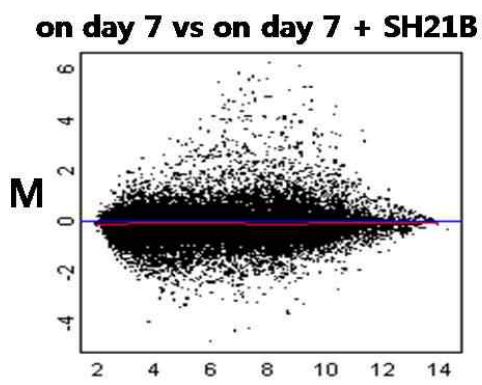

A

Fig. 1. MA plot after normalization. (A) The comparison between preadipocytes (on day 0) and differentiated adipocytes (on day 7). (B) The comparison between preadipocytes (on day 0) and differentiated adipocytes with $100 \mathrm{\mu g} / \mathrm{ml} \mathrm{SH21B} \mathrm{(on} \mathrm{day}$ $7+$ SH21B). (C) The comparison between $0 \mu \mathrm{g} / \mathrm{ml} \mathrm{SH21B}$ treatment and $100 \mu \mathrm{g} / \mathrm{ml} \mathrm{SH} 21 \mathrm{~B}$ treatment in differentiated adipocytes.

유의하게 증가 혹은 감소된 값을 가지는 유전자를 분류하는 differentially expressed gene (DEG) 분석에 적용되었다. 그 결과, 'on day 0' 시료와 비교하여 2배 이상 유의하게 증가 혹은 감소한 유전자의 수는 'on day 7 ' 시료에서 1,590개(증가; 949개, 감소; 641개), 'on day $7+$ SH21B' 시료에서 898개(증가; 443개, 감소; 455개)였다(Table 1). 또한, SH21B를 처리하지 않 은, 'on day 7 ' 시료 와 처리한 'on day $7+\mathrm{SH} 21 \mathrm{~B}^{\prime}$ 시료의 비교에서, 2 배 이상 증가 혹은 감소한 유전자 수는 1,516 개(증 가; 746 개, 감소; 770 개)였다. 이러한 결과는 지방세포가 분화 될 때, 수많은 유전자들의 발현이 변화되고 서로 작용함을 제 시하며, $\mathrm{SH} 21 \mathrm{~B}$ 의 첨가가 이러한 유전자들의 발현을 억제하거 나 유도하면서 지방세포형성에 영향을 주는 것을 의미한다.

\section{Hierarchical clustering과 $\mathrm{K}$-means clustering을 통} 한 유전자 발현 양상의 분석

지방세포 분화 시, $\mathrm{SH} 21 \mathrm{~B}$ 에 의해 변화되는 유전자들의 특 징을 분석하기 위해 Table 1 의 유의 유전자들에 대해 군집 분 석을 수행하였다. Table 1 의 유의 유전자, 총 2,568 개에 대하여 hierarchical clustering을 진행한 결과, 전지방세포에서 지방 세포로 분화 될 때와 SH21B의 첨가 유무에 따라 다양한 발현

Table 1. Number of genes of which expression levels were changed more than 2 fold

\begin{tabular}{lccr}
\hline & up & down & \multicolumn{1}{c}{ total } \\
\hline on day 0 vs on day 7 & 949 & 641 & 1,590 \\
on day 0 vs on day $7+$ SH21B & 443 & 455 & 898 \\
on day 7 vs on day $7+$ SH21B & 746 & 770 & 1,516 \\
\hline
\end{tabular}

The genes are selected if their expression levels were changes more than 2-fold compared with undifferentiated preadipocyte or untreated adipocyte.
양상이 나타났다(Fig. 2.) Hierarchical clustering에서 나타나 는 유전자 발현 양상을 좀 더 자세히 분석하고 분류하기 위하 여 K-means clustering을 수행하였다(Fig. 3.). K-means clus-

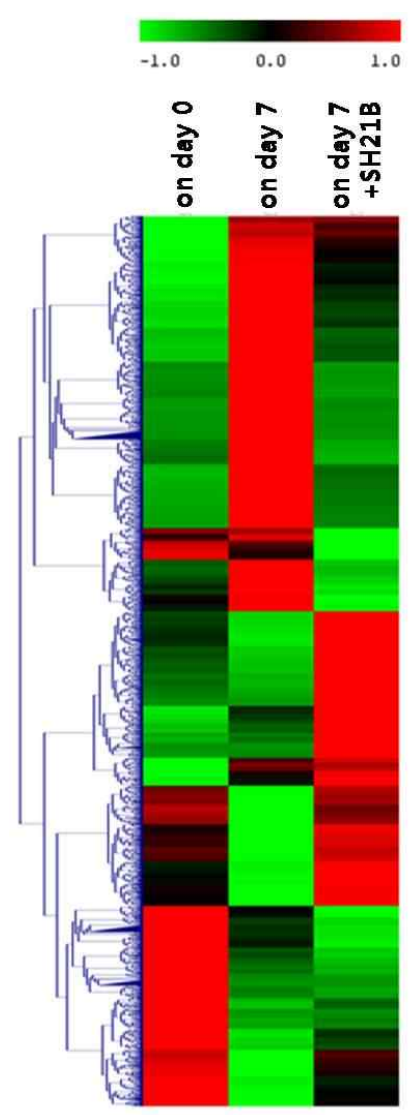

Fig. 2. Hierarchical clustering analyses of 2,568 selected genes. The red color refers to the up-regulation of the gene expression and the green color indicates the down-regulation of the gene expression compared with the mean value. 

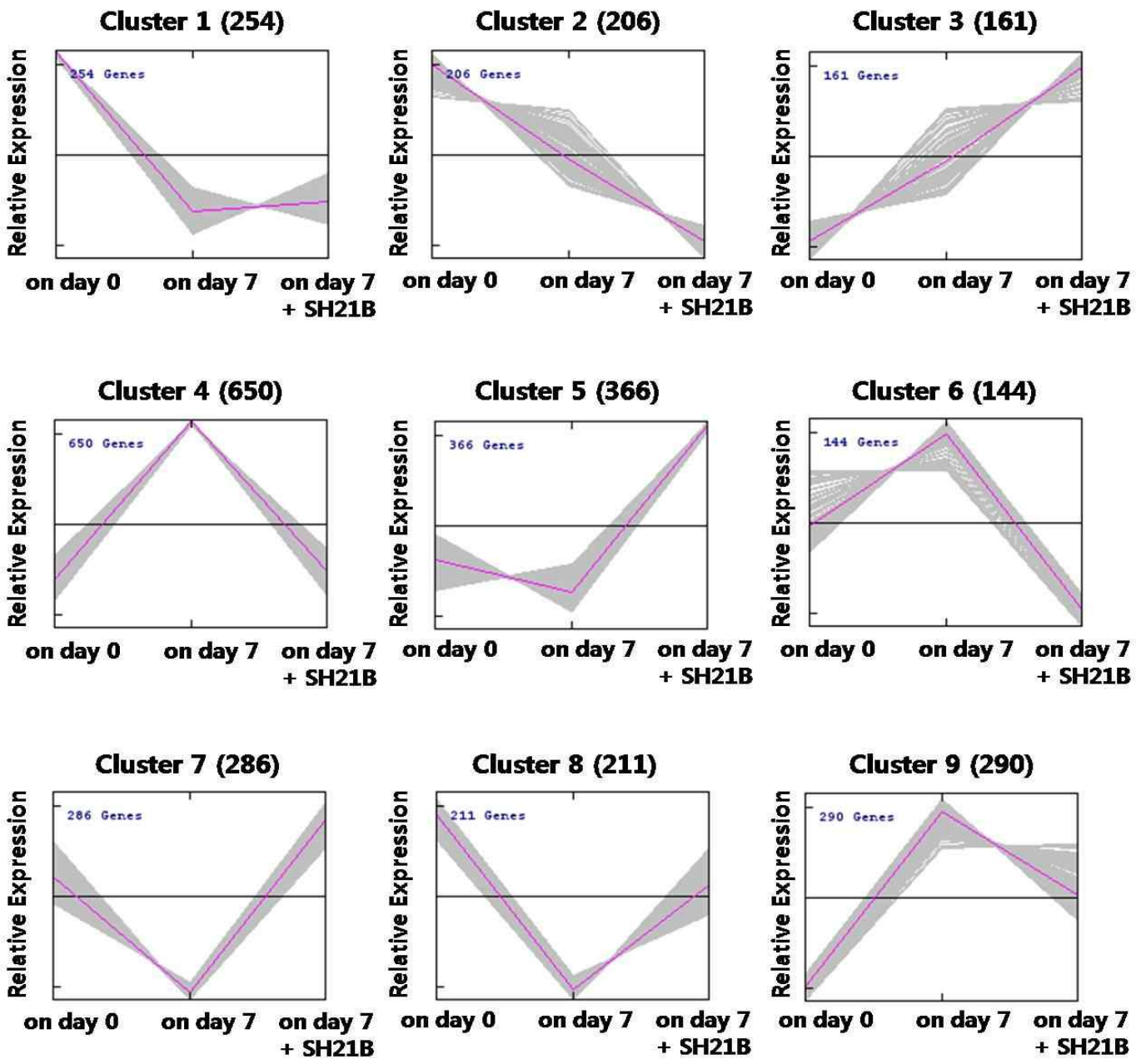

Fig. 3. The expression profiles of each clusters (cluster 1-9) in the K-means clustering analysis. The y-axis represents relative expression levels and the $x$-axis represents the sample names.

Table 2. List of genes in each cluster

\begin{tabular}{|c|c|c|c|c|c|}
\hline Cluster & $\begin{array}{l}\text { No. of } \\
\text { genes }\end{array}$ & Acession No. & $\begin{array}{l}\text { Gene } \\
\text { symbol }\end{array}$ & Gene title & Biological function \\
\hline \multirow[t]{13}{*}{1} & 254 & NM_009828 & Ccna2 & cyclin A2 & cell cycle regulation \\
\hline & & NM_172301 & Ccnb1 & cyclin B1 & cell cycle regulation \\
\hline & & NM_007634 & Conf & cyclin F & cell cycle regulation \\
\hline & & NM_011799 & Cdc6 & cell division cycle 6 homolog & cell cycle regulation \\
\hline & & NM_008008 & Fgf7 & fibroblast growth factor 7 & cell proliferation regulation \\
\hline & & NM_010216 & Figf & c-fos induced growth factor & cell proliferation regulation \\
\hline & & NM_008655 & Gadd45b & growth arrest and DNA-damage-inducible 45 beta & cell cycle regulation \\
\hline & & NM_008087 & Gas2 & growth arrest specific 2 & cell cycle regulation \\
\hline & & NM_031166 & Id 4 & inhibitor of DNA binding 4 & cell proliferation regulation \\
\hline & & NM_001083188 & Lig1 & ligase I, DNA, ATP-dependent & cell cycle regulation \\
\hline & & NM_019971 & Pdgfc & platelet-derived growth factor, $\mathrm{C}$ polypeptide & cell proliferation regulation \\
\hline & & NM_012025 & Racgap1 & Rac GTPase-activating protein 1 & cell cycle regulation \\
\hline & & NM_009506 & Vegfc & vascular endothelial growth factor $\mathrm{C}$ & cell proliferation regulation \\
\hline \multirow[t]{4}{*}{2} & 206 & NM_007630 & Ccnb2 & cyclin B2 & cell cycle regulation \\
\hline & & NM_010128 & Emp1 & epithelial membrane protein 1 & cell growth regulation \\
\hline & & NM_010207 & Fgfr2 & fibroblast growth factor receptor 2 & cell proliferation regulation \\
\hline & & NM_019521 & Gas6 & growth arrest specific 6 & cell growth regulation \\
\hline
\end{tabular}


Table 2. Continued

\begin{tabular}{|c|c|c|c|c|c|}
\hline \multirow[t]{10}{*}{ Cluster } & $\begin{array}{c}\text { No. of } \\
\text { genes }\end{array}$ & Acession No. & $\begin{array}{c}\text { Gene } \\
\text { symbol }\end{array}$ & Gene title & Biological function \\
\hline & & NM_008090 & Gata2 & GATA binding protein 2 & cell differentaion process \\
\hline & & NM_010427 & Hgf & hepatocyte growth factor & cell proliferation regulation \\
\hline & & NM_010512 & Igf1 & insulin-like growth factor 1 & cell differentaion process \\
\hline & & NM_008048 & Igfbp7 & insulin-like growth factor binding protein 7 & cell growth regulation \\
\hline & & NM_019499 & Mad211 & MAD2 (mitotic arrest deficient, homolog)-like 1 & cell cycle regulation \\
\hline & & NM_011050 & Pdcd4 & programmed cell death 4 & cell cycle regulation \\
\hline & & NM_175445 & Rassf2 & Ras association (RalGDS/AF-6) domain family member 2 & cell cycle regulation \\
\hline & & NM_030261 & Sesn3 & sestrin 3 & cell cycle regulation \\
\hline & & NM_011874 & Smc4 & structural maintenance of chromosomes 4 & cell cycle regulation \\
\hline \multirow[t]{10}{*}{3} & 161 & NM_134188 & Acot2 & acyl-CoA thioesterase 2 & lipid metabolic process \\
\hline & & NM_011804 & Creg1 & cellular repressor of E1A-stimulated genes 1 & cell growth regulation \\
\hline & & NM_025380 & Eefle1 & eukaryotic translation elongation factor 1 epsilon 1 & cell proliferation regulation \\
\hline & & NM_023913 & Ern1 & endoplasmic reticulum (ER) to nucleus signalling 1 & cell cycle regulation \\
\hline & & NM_153569 & Gak & cyclin G associated kinase & cell cycle regulation \\
\hline & & NM_010849 & Myc & myelocytomatosis oncogene & cell proliferation regulation \\
\hline & & NM_176840 & Osbpl11 & oxysterol binding protein-like 11 & lipid metabolic process \\
\hline & & NM_007453 & Prdx6 & peroxiredoxin 6 & lipid metabolic process \\
\hline & & NM_001039521 & Rrn3 & RRN3 RNA polymerase I transcription factor homolog & cell proliferation regulation \\
\hline & & NM_011577 & Tgfb1 & transforming growth factor, beta 1 & cell growth regulation \\
\hline \multirow[t]{31}{*}{4} & 650 & NM_009605 & Adipoq & adiponectin, $\mathrm{C} 1 \mathrm{Q}$ and collagen domain containing & fatty acid biosynthetic process \\
\hline & & NM_007469 & Apoc1 & apolipoprotein C-I & lipid metabolic process \\
\hline & & NM_009695 & Apoc2 & apolipoprotein C-II & lipid metabolic process \\
\hline & & NM_009744 & Bcl6 & B-cell leukemia/lymphoma 6 & cell proliferation regulation \\
\hline & & NM_022021 & Cables1 & Cdk5 and Abl enzyme substrate 1 & cell cycle regulation \\
\hline & & NM_016900 & Cav2 & caveolin 2 & cell proliferation regulation \\
\hline & & NM_017367 & Coni & cyclin I & cell cycle regulation \\
\hline & & NM_007678 & Cebpa & CCAAT/enhancer binding protein (C/EBP), alpha & adipogenesis precess \\
\hline & & NM_010634 & Fabp5 & fatty acid binding protein 5 , epidermal & lipid metabolic process \\
\hline & & NM_007988 & Fasn & fatty acid synthase & fatty acid biosynthetic process \\
\hline & & NM_008002 & Fgf10 & fibroblast growth factor 10 & cell proliferation regulation \\
\hline & & NM_054071 & Fgfrl1 & fibroblast growth factor receptor-like 1 & cell proliferation regulation \\
\hline & & NM_019739 & Foxo1 & forkhead box $\mathrm{O} 1$ & cell proliferation regulation \\
\hline & & NM_008059 & G0s2 & G0/G1 switch gene 2 & cell cycle regulation \\
\hline & & NM_011817 & Gadd45g & growth arrest and DNA-damage-inducible 45 gamma & cell cycle regulation \\
\hline & & NM_010433 & Hipk2 & homeodomain interacting protein kinase 2 & cell proliferation regulation \\
\hline & & NM_139269 & Hrasls3 & HRAS like suppressor 3 & cell cycle regulation \\
\hline & & NM_139269 & Hrasls3 & HRAS like suppressor 3 & cell cycle regulation \\
\hline & & NM_001122737 & Igf2 & insulin-like growth factor 2 & cell proliferation regulation \\
\hline & & NM_021878 & Jarid2 & jumonji, AT rich interactive domain 2 & cell proliferation regulation \\
\hline & & NM_010719 & Lipe & lipase, hormone sensitive & lipid metabolic process \\
\hline & & NM_015806 & Mapk6 & mitogen-activated protein kinase 6 & cell cycle regulation \\
\hline & & NM_001005863 & Mtus1 & mitochondrial tumor suppressor 1 & cell cycle regulation \\
\hline & & NM_001127330 & Pparg & peroxisome proliferator activated receptor gamma & adipogenesis precess \\
\hline & & NM_009029 & $\mathrm{Rb} 1$ & retinoblastoma 1 & cell proliferation regulation \\
\hline & & NM_009061 & Rgs2 & regulator of G-protein signaling 2 & cell cycle regulation \\
\hline & & NM_011480 & Srebf1 & sterol regulatory element binding transcription factor 1 & adipogenesis precess \\
\hline & & NM_178667 & Tfdp2 & transcription factor Dp 2 & cell cycle regulation \\
\hline & & NM_001009935 & Txnip & thioredoxin interacting protein & cell cycle regulation \\
\hline & & NM_009464 & Ucp3 & uncoupling protein 3 & fatty acid biosynthetic process \\
\hline & & NM_001033324 & Zbtb16 & zinc finger and BTB domain containing 16 & cell proliferation regulation \\
\hline
\end{tabular}


Table 2. Continued

\begin{tabular}{|c|c|c|c|c|c|}
\hline Cluster & $\begin{array}{l}\text { No. of } \\
\text { genes }\end{array}$ & Acession No. & $\begin{array}{l}\text { Gene } \\
\text { symbol }\end{array}$ & Gene title & Biological function \\
\hline \multirow[t]{21}{*}{5} & \multirow[t]{21}{*}{366} & NM_019816 & Aatf & apoptosis antagonizing transcription factor & cell cycle regulation \\
\hline & & NM_019673 & Actl6a & actin-like $6 \mathrm{~A}$ & cell growth regulation \\
\hline & & NM_007396 & Acvr2a & activin receptor IIA & cell proliferation regulation \\
\hline & & NM_028835 & Atg7 & autophagy-related 7 (yeast) & lipid metabolic process \\
\hline & & NM_009846 & $\mathrm{Cd} 24 \mathrm{a}$ & CD24a antigen & cell proliferation regulation \\
\hline & & NM_001122893 & Fyn & Fyn proto-oncogene & cell proliferation regulation \\
\hline & & NM_010441 & Hmga2 & high mobility group AT-hook 2 & cell growth regulation \\
\hline & & AK047224 & Mafg & v-maf musculoaponeurotic fibrosarcoma oncogene family, protein $G$ & cell proliferation regulation \\
\hline & & NM_010864 & Myo5a & myosin $\mathrm{Va}$ & fatty acid biosynthetic process \\
\hline & & NM_021315 & Noc31 & nucleolar complex associated 3 homolog & fatty acid biosynthetic process \\
\hline & & NM_009981 & Pcytla & phosphate cytidylyltransferase 1 , choline, alpha isoform & lipid metabolic process \\
\hline & & NM_133757 & Pgs1 & phosphatidylglycerophosphate synthase 1 & lipid metabolic process \\
\hline & & NM_008869 & Pla2g4a & phospholipase A2, group IVA & lipid metabolic process \\
\hline & & NM_145610 & Ppan & peter pan homolog (Drosophila) & cell growth regulation \\
\hline & & NM_019766 & Ptges3 & prostaglandin E synthase 3 & fatty acid biosynthetic process \\
\hline & & NM_011198 & Ptgs2 & prostaglandin-endoperoxide synthase 2 & fatty acid biosynthetic process \\
\hline & & NM_177103 & Senp5 & SUMO/sentrin specific peptidase 5 & cell cycle regulation \\
\hline & & NM_009163 & Sgpl1 & sphingosine phosphate lyase 1 & lipid metabolic process \\
\hline & & NM_009230 & Soat1 & sterol O-acyltransferase 1 & lipid metabolic process \\
\hline & & NM_009372 & Tgif1 & TGFB-induced factor homeobox 1 & cell proliferation regulation \\
\hline & & NM_001042523 & Txnrd1 & thioredoxin reductase 1 & cell proliferation regulation \\
\hline \multirow[t]{8}{*}{6} & \multirow[t]{8}{*}{144} & NM_009696 & Apoe & apolipoprotein E & lipid metabolic process \\
\hline & & NM_018830 & Asah2 & $\mathrm{N}$-acylsphingosine amidohydrolase 2 & lipid metabolic process \\
\hline & & NM_007671 & $\mathrm{Cdkn} 2 \mathrm{c}$ & cyclin-dependent kinase inhibitor $2 \mathrm{C}$ & cell proliferation regulation \\
\hline & & NM_008256 & Hmgcs2 & 3-hydroxy-3-methylglutaryl-Coenzyme A synthase 2 & lipid metabolic process \\
\hline & & NM_027881 & Osbpl3 & oxysterol binding protein-like 3 & lipid metabolic process \\
\hline & & NM_008968 & Ptgis & prostaglandin I2 (prostacyclin) synthase & fatty acid biosynthetic process \\
\hline & & NM_019942 & Sept6 & septin 6 & cell cycle regulation \\
\hline & & NM_001013370 & Sesn1 & sestrin 1 & cell cycle regulation \\
\hline \multirow[t]{22}{*}{7} & \multirow[t]{22}{*}{286} & NM_027976 & Acsl5 & acyl-CoA synthetase long-chain family member 5 & fatty acid biosynthetic process \\
\hline & & NM_026201 & Ccar1 & cell division cycle and apoptosis regulator 1 & cell cycle regulation \\
\hline & & NM_013495 & Cptla & carnitine palmitoyltransferase $1 \mathrm{a}$, liver & fatty acid biosynthetic process \\
\hline & & NM_007614 & Ctnnb1 & catenin, beta 1 & adipogenesis precess \\
\hline & & NM_007825 & Cyp7b1 & cytochrome P450, family 7 , subfamily b, polypeptide 1 & lipid metabolic process \\
\hline & & NM_010516 & Cyr61 & cysteine rich protein 61 & cell growth regulation \\
\hline & & NM_130450 & Elovl6 & ELOVL family member 6 , elongation of long chain fatty acids & fatty acid biosynthetic process \\
\hline & & NM_007948 & Ercc1 & $\begin{array}{l}\text { excision repair cross-complementing rodent repair deficiency, } \\
\text { complementation group } 1\end{array}$ & cell proliferation regulation \\
\hline & & NM_008094 & Gba & glucosidase, beta, acid & lipid metabolic process \\
\hline & & NM_010421 & Hexa & hexosaminidase $\mathrm{A}$ & lipid metabolic process \\
\hline & & NM_008255 & Hmgcr & 3-hydroxy-3-methylglutaryl-Coenzyme A reductase & lipid metabolic process \\
\hline & & M13967 & Hspa8 & heat shock protein 8 & cell cycle regulation \\
\hline & & NM_010590 & Jub & ajuba & cell cycle regulation \\
\hline & & NM_010807 & Marcksl1 & MARCKS-like 1 & cell proliferation regulation \\
\hline & & NM_181409 & Mtmr11 & myotubularin related protein 11 & lipid metabolic process \\
\hline & & NM_010930 & Nov & nephroblastoma overexpressed gene & cell growth regulation \\
\hline & & NM_024289 & Osbpl5 & oxysterol binding protein-like 5 & lipid metabolic process \\
\hline & & NM_010329 & Pdpn & podoplanin & cell proliferation regulation \\
\hline & & NM_008862 & Pkia & protein kinase inhibitor, alpha & cell cycle regulation \\
\hline & & NM_152804 & Plk2 & polo-like kinase 2 (Drosophila) & cell cycle regulation \\
\hline & & NM_008969 & Ptgs1 & prostaglandin-endoperoxide synthase 1 & fatty acid biosynthetic process \\
\hline & & NM_011237 & $\operatorname{Rad} 9$ & RAD9 homolog (S. pombe) & cell cycle regulation \\
\hline
\end{tabular}


Table 2. Continued

\begin{tabular}{|c|c|c|c|c|c|}
\hline Cluster & $\begin{array}{l}\text { No. of } \\
\text { genes }\end{array}$ & Acession No. & $\begin{array}{l}\text { Gene } \\
\text { symbol }\end{array}$ & Gene title & Biological function \\
\hline & & NM_011448 & Sox9 & SRY-box containing gene 9 & cell proliferation regulation \\
\hline & & NM_011610 & Tnfrsflb & tumor necrosis factor receptor superfamily, member $1 \mathrm{~b}$ & cell proliferation regulation \\
\hline & & NM_016873 & Wisp2 & WNT1 inducible signaling pathway protein 2 & cell growth regulation \\
\hline & & NM_009533 & Xrcc5 & X-ray repair complementing defective repair in Chinese hamster cells 5 & cell proliferation regulation \\
\hline \multirow[t]{25}{*}{8} & \multirow[t]{25}{*}{211} & NM_001009818 & Sept11 & septin 11 & cell cycle regulation \\
\hline & & NM_009728 & Atp10a & ATPase, class $\mathrm{V}$, type $10 \mathrm{~A}$ & lipid metabolic process \\
\hline & & NM_007631 & Ccnd1 & cyclin D1 & adipogenesis precess \\
\hline & & NM_028083 & Chaf1b & chromatin assembly factor 1 , subunit $B$ & cell cycle regulation \\
\hline & & NM_007691 & Chek1 & checkpoint kinase 1 homolog & cell cycle regulation \\
\hline & & NM_153679 & Cpt1c & carnitine palmitoyltransferase $1 \mathrm{c}$ & fatty acid biosynthetic process \\
\hline & & NM_007778 & Csf1 & colony stimulating factor 1 & cell proliferation regulation \\
\hline & & NM_001012477 & Cxcl12 & chemokine (C-X-C motif) ligand 12 & cell proliferation regulation \\
\hline & & NM_013726 & Dbf4 & DBF4 homolog (S. cerevisiae) & cell cycle regulation \\
\hline & & NM_022563 & Ddr2 & discoidin domain receptor family, member 2 & cell proliferation regulation \\
\hline & & NM_010129 & Emp3 & epithelial membrane protein 3 & cell growth regulation \\
\hline & & NM_007950 & Ereg & epiregulin & cell proliferation regulation \\
\hline & & NM_008234 & Hells & helicase, lymphoid specific & cell cycle regulation \\
\hline & & NM_010422 & Hexb & hexosaminidase B & lipid metabolic process \\
\hline & & NM_023627 & Isyna1 & myo-inositol 1-phosphate synthase A1 & lipid metabolic process \\
\hline & & NM_013584 & Lifr & leukemia inhibitory factor receptor & cell proliferation regulation \\
\hline & & NM_008564 & $\mathrm{Mcm} 2$ & minichromosome maintenance deficient 2 mitotin & cell cycle regulation \\
\hline & & NM_008563 & Mcm3 & minichromosome maintenance deficient 3 & cell cycle regulation \\
\hline & & NM_008567 & Mcm6 & minichromosome maintenance deficient 6 & cell cycle regulation \\
\hline & & NM_023294 & Ndc80 & NDC80 homolog, kinetochore complex component & cell cycle regulation \\
\hline & & NM_008861 & Pkd2 & polycystic kidney disease 2 & cell cycle regulation \\
\hline & & NM_013737 & Pla2g7 & phospholipase A2, group VII & lipid metabolic process \\
\hline & & NM_175686 & Prrx1 & paired related homeobox 1 & cell proliferation regulation \\
\hline & & NM_011313 & S100a6 & S100 calcium binding protein A6 & cell proliferation regulation \\
\hline & & NM_009365 & Tgfb1i1 & transforming growth factor beta 1 induced transcript 1 & fatty acid biosynthetic process \\
\hline \multirow[t]{22}{*}{9} & \multirow[t]{22}{*}{290} & NM_009593 & Abcg1 & ATP-binding cassette, sub-family G (WHITE), member 1 & lipid metabolic process \\
\hline & & NM_026179 & Abhd5 & abhydrolase domain containing 5 & lipid metabolic process \\
\hline & & NM_133360 & Acaca & acetyl-Coenzyme A carboxylase alpha & fatty acid biosynthetic process \\
\hline & & NM_172656 & Als2cr2 & amyotrophic lateral sclerosis 2 & cell cycle regulation \\
\hline & & NM_021893 & $\mathrm{Cd} 274$ & CD274 antigen & cell proliferation regulation \\
\hline & & NM_013642 & Dusp1 & dual specificity phosphatase 1 & cell cycle regulation \\
\hline & & NM_153526 & Insig1 & insulin induced gene 1 & lipid metabolic process \\
\hline & & NM_172266 & Lpgat1 & lysophosphatidylglycerol acyltransferase 1 & lipid metabolic process \\
\hline & & NM_008509 & Lpl & lipoprotein lipase & lipid metabolic process \\
\hline & & NM_025297 & Mecr & mitochondrial trans-2-enoyl-CoA reductase & fatty acid biosynthetic process \\
\hline & & NM_010798 & Mif & macrophage migration inhibitory factor & cell proliferation regulation \\
\hline & & NM_019926 & Mtm1 & X-linked myotubular myopathy gene 1 & lipid metabolic process \\
\hline & & NM_023651 & Pex13 & peroxisomal biogenesis factor 13 & fatty acid biosynthetic process \\
\hline & & NM_016915 & Pla2g6 & phospholipase A2, group VI & lipid metabolic process \\
\hline & & NM_011145 & Ppard & peroxisome proliferator activator receptor delta & adipogenesis precess \\
\hline & & NM_011183 & Psen2 & presenilin 2 & fatty acid biosynthetic process \\
\hline & & NM_133783 & Ptges2 & prostaglandin E synthase 2 & fatty acid biosynthetic process \\
\hline & & NM_007483 & Rhob & ras homolog gene family, member $\mathrm{B}$ & cell cycle regulation \\
\hline & & NM_009128 & Scd2 & stearoyl-Coenzyme A desaturase 2 & fatty acid biosynthetic process \\
\hline & & NM_028943 & Sgms2 & sphingomyelin synthase 2 & lipid metabolic process \\
\hline & & NM_013671 & Sod2 & superoxide dismutase 2 , mitochondrial & fatty acid biosynthetic process \\
\hline & & NM_009415 & Tpi1 & triosephosphate isomerase 1 & fatty acid biosynthetic process \\
\hline
\end{tabular}

The GenBank accession number, gene symbol, gene title and biological function are included. 
tering을 통해 분류된 군집들은 지방세포가 분화될 때 그리고 $\mathrm{SH} 21 \mathrm{~B}$ 의 첨가 유무에 따라 완전히 다른 양상을 보였다. 9 개의 군집 중 지방세포형성이 유도될 때 증가했다가 $\mathrm{SH} 21 \mathrm{~B}$ 의 첨가 에 의해 크게 감소하는 양상을 보이는 군집들(cluster 4, cluster 6, cluster 9)과 이와는 반대로 지방세포형성이 유도될 때 감소되었다가 $\mathrm{SH} 21 \mathrm{~B}$ 에 의해 크게 증가하는 양상을 보이는 군 집들(cluster 7, cluster 8)을 따로 선별하였다. 지방세포형성 시, 유전자 발현이 증가되었다가 SH21B에 의해 억제되는 양상 을 보이는 cluster 4, cluster 6 및 cluster 9에는 지방세포형성 유도인자(pro-adipogenic factor) 및 세포증식(cell proliferation) 억제인자가 다수 포함되었다. 반대로 지방세포형성 시, 유전 자 발현이 억제되다가 $\mathrm{SH} 21 \mathrm{~B}$ 에 의해 증가되는 양상을 보이는 cluster 7 과 cluster 8 에는 지방세포형성 억제인자(anti-adipogenic factor) 및 세포증식 유도인자가 다수 포함되었다. 이러 한 군집에 포함되는 유의 유전자들은 Table 2에 자세히 표기되 었다.

\section{고 찰}

에너지 저장과 지질대사 조절 등의 기능을 가지는 지방세포 는 생체 내에서 꼭 필요한 부분이다. 지방세포의 기능 장애는 비정상적인 지방조직의 형성으로 인한 비만의 발생을 유도하 고 제 2 당뇨를 포함한 대사성 질환을 야기한다[32]. 지방세포 의 핵심적인 기능인 지방세포형성은 C/EBPs와 $\operatorname{PPAR} \gamma$ 를 중 심으로 수많은 유전자의 발현이 조절되면서 진행되는데, 이러 한 지방세포형성 관련 유전자들은 비만 및 각종 성인병 치료 연구의 주요 대상이 되고 있다. 최근, 부작용이 비교적 적은 천연물질을 생명과학에 적용시켜 질병을 치료하거나 대사를 조절하는 연구가 늘어나고 있다 $[1,30,31]$. 이전의 연구에서, 본 연구진은 생약복합물인 SH21B가 지방축적의 억제 및 지방세 포형성 관련 인자들의 발현을 조절함을 밝혔다[18]. SH21B의 성분을 high performance liquid chromatography 를 사용하여 분석한 결과, 바이칼린(baicalin)이 $11.4 \%$ 로 가장 높은 비중을 차지하는 주요 성분으로 분석되었다. 플라보노이드(flavonoid) 계열의 바이칼린은 최근 본 연구진에 의해 지방세포형성과 지질형성을 억제하는 것으로 보고된 바 있다[17]. 이번 연구에 서는 microarray 분석을 이용하여 SH21B에 의한 지방세포형 성 억제 시, 유의한 발현 변화를 가지는 유전자들을 분석하고 분류하여 그 발현 양상을 밝히고자 하였다.

지방세포형성은 cell proliferation (세포증식) 작용에 포함 되는 cell cycle regulator (세포주기 조절자), cell growth regulator (세포성장 조절자) 그리고 지방세포형성 조절자들의 발 현과 밀접한 관련을 가진다[10]. 성장 및 증식 중인 전지방세포 에 분화의 요건이 갖춰지면 세포 분열이 중지되는데, 이 상태 에서 cell cycle이 몇 번 더 진행된 후 지방세포의 분화가 유도 된다. 이번 연구에서 전지방세포, 분화된 지방세포 그리고
$\mathrm{SH} 21 \mathrm{~B}$ 에 의해 분화가 억제된 지방세포의 전체 유전자 발현은 그 양상이 크게 달랐다. 각 시료들을 비교한 결과에서 총 2,568 개의 유전자가 2 배 이상의 유의성을 보였고(Table 1) 이 유전 자들의 발현 양상을 분석하여 분류한 결과 9 개의 군집을 형성 할 수 있었다(Fig. 3). 9 개의 군집 중 지방세포의 분화 및 $\mathrm{SH} 21 \mathrm{~B}$ 의 첨가에 특징적인 양상을 보이는 cluster 4, cluster6, cluster 7, cluster 8 및 cluster 9에는 지방세포형성과 세포증식 에 관련된 주요 유전자들이 다수 포함되었다.

cluster 4, cluster6 및 cluster 9에 포함된 유전자들은 지방세 포가 분화하면서 발현이 크게 증가했다가 $\mathrm{SH} 21 \mathrm{~B}$ 의 첨가에 의 해 현저히 감소되는 양상을 가진다. 특히, Cluster 4 와 Cluster 9에는 지방세포 유도 및 최종마커에 해당하는 유전자들이 다 수 포함되었다. Cluster 4에 포함된 PPAR $\gamma$ 와 $\mathrm{C} / \mathrm{EBPa}$ 는 지방 세포형성의 핵심적인 전사인자로 알려져 있다[24]. PPAR $\gamma$ 와 $\mathrm{C} / \mathrm{EBPa}$ 를 각각 과다 발현한 섬유아세포는 지방세포형성 유 도물질 없이 단독으로 지방세포의 분화를 유도할 수 있다 [12,34]. 이번 연구에서, 지방세포의 분화 과정 중 두 유전자의 발현이 증가했다가 SH21B에 의해 억제되는 유전자 발현 양상 은 SH21B의 지방세포형성 억제 효과를 재확인해준다. 3T3-L1 지방세포 모델에서 $\mathrm{PPAR} \gamma$ 와 $\mathrm{C} / \mathrm{EBPa}$ 의 발현 상승은 지방세 포형성을 유도하고 최종마커의 발현을 증가시킨다고 알려져 있다[29]. Cluster 4에 포함된 ADIPOQ와 fatty acid synthase (FASN), cluster 9에 포함된 LPL등은 지방산 생성과정(fatty acid biosynthesis process)과 지질 대사과정(lipid metabolic process)에 관여하는 대표적인 지방세포형성 최종마커들이다. 분화가 진행되면서 증가하였다가 $\mathrm{SH} 21 \mathrm{~B}$ 에 의해 감소되는 $\mathrm{ADIPOQ}, \mathrm{FASN}$ 및 LPL 등의 유전자 발현 양상의 결과는 $\mathrm{SH} 21 \mathrm{~B}$ 에 의한 $\mathrm{PPAR} \gamma$ 와 $\mathrm{C} / \mathrm{EBPa}$ 의 발현 양상 결과와 부합 된다. 인슐린 자극에 의해 조절되는 sterol regulatory element binding transcription factor1 (SREBF1)은 PPAR $\gamma$ 의 발현을 유도하는 상위 조절자로 알려져 있다[11]. 이번 microarray 분 석에서 SREBF1의 발현 양상도 PPAR $\gamma$ 와 함께 cluster 4 에 포함되었다. 그 외에도 지질대사와 지방산 생성에 관련된 많 은 유전자들이 cluster 4 (apolipoprotein C-I (APOC1), uncoupling protein 3 (UCP3) 등), cluster 6 (apolipoprotein E (APOE), 3-hydroxy-3-methylglutaryl-Coenzyme A synthase 2 (HMGCS2) 등), cluster 9 (ATP-binding cassette, sub-family $\mathrm{G}$, member 1 (ABCG1), superoxide dismutase 2 (SOD2) 등)에 포함되었다. 이러한 결과는 정상적인 지방세포형성의 유도가 진행되었음을 나타내며 SH21B의 지방세포형성 억제 효능이 지방세포형성 유도에 관여하는 유전자를 억제하여 나타남을 제시한다.

Cluster 4, cluster 6 그리고 cluster 9에는 cell proliferation, cell growth, cell cycle을 억제하는 유전자들이 다수 포함되었 다. Cluster 4의 B-cell leukemia/lymphoma6 (BCL6)는 cell proliferation을 억제하는 것으로 알려져 있다. BCL6는 B cell 
에서 NF-kappaB와 결합하여 전사를 억제하는데 BCL6가 제 거된 마우스의 macrophage (대식세포)는 그 수가 크게 증가하 는 것으로 보고되었다[7]. 또한, 종양 억제인자인 retinoblastoma1 (RB1) 역시 SH21B에 의해 억제되는 유전자 발현 양상을 가지는 cluster4에 포함되었다. Bajenaru ML 등은 RB1 과 neurofibromatosis1 (NF1) 두 유전자를 조작한 mice heterozygous의 성상세포(astrocyte)의 수가 3 배까지 상승하는 것 을 보였고, Sage 등은 암세포에서 RB1을 제거 했을 때, 정지되 었던 cell cycle의 작동이 재유도 됨을 밝혔다[3,26]. Cluster 6에 포함되는 cyclin-dependent kinase inhibitor 2C (CDKN2C)는 INK4C, p18, p18-INK4C 등으로 불리는데, Bai 등은 마우스에서 $\mathrm{CDKN} 2 \mathrm{C}$ 를 제거하여 종양세포 수가 증식되 는 것을 보임으로써 $\mathrm{CDKN} 2 \mathrm{C}$ 의 cell proliferation 억제 기능 을 보였다[2]. Cluster 9의 발현 양상을 가지는 ras homolog gene family, member B (RHOB)는 cell cycle을 억제하는 것으 로 알려져 있다. RHOB를 제거한 세포를 RHOB가 제거된 마 우스에 이식하였을 경우, RHOB의 cell cycle 억제 기능이 상실 됨으로써 피부암 감수성이 증가되었다[19]. 언급한 유전자들 외에도 proliferation과 관련된 유전자들이 cluster 4 (caveolin 2 (CAV2), fibroblast growth factor 10 (FFG10), zinc finger and BTB domain containing 16 (ZBTB16) 등), cluster 6 (septin 6 (SEPT6), sestrin 1 (SESN1) 등), cluster 9 (CD274 antigen (CD274), macrophage migration inhibitory factor (MIF) 등)에 다수 포함되었다. 이러한 결과들은 SH21B가 세포 증식을 억제하는 기능을 가진 유전자들의 발현을 조절하여 지방세포형성을 억제함을 제시한다.

이와는 반대로, Cluster 7과 Cluster 8에 포함된 유전자들은 지방세포가 분화하면서 발현이 급격히 감소했다가 $\mathrm{SH} 21 \mathrm{~B}$ 의 첨가에 의해 크게 증가하는 양상을 가진다. cluster 7 과 cluster 8 에는 지방세포형성 억제와 관련된 유전자들과 세포증식을 유도하는 유전자들이 다수 포함되었다. WNT/ $\beta$-catenin pathway는 대표적인 지방세포형성 억제 경로이다 $[5,25]$. $\mathrm{WNT} / \beta$-catenin pathway의 활성화는 $\beta$-catenin 단백질 분해 를 저해하여 세포질에서 핵 속으로 $\beta$-catenin의 이동을 유도한 다. 핵 속으로 이동한 $\beta$ - catenin은 cyclin D1 (CCND1), matrix metallopeptidase 7 (MMP-7) 등의 발현을 증가시키고 그 결과 로 $\mathrm{PPAR} \gamma$ 와 $\mathrm{C} / \mathrm{EBPa}$ 의 발현을 억제함으로써 지방세포형성 을 저해한다. Cluster 7에 포함된 $\beta$-catenin은 WNT/ $\beta$-catenin pathway의 핵심 인자로 지방세포형성을 저해하는 매개체로 알려져 있다[5]. 다양한 조직 및 세포에서 cell cycle과 cell proliferation을 유도한다고 알려져 있는 CCND1은[6,33], clsuter 8 의 발현 양상을 가지는 것으로 나타났다. 또한, CCND1은 앞에서 언급한대로 $\beta$-catenin에 의해 발현되어 $\operatorname{PPAR} \gamma$ 를 억 제하는 지방세포형성 억제 인자로 알려져 있다[15].

Cluster 7과 Cluster 8에는 또한 cell proliferation, cell cycle 및 cell growth를 유도하는 인자들이 많이 발견되었다. Cluster
7에 포함되는 MARCKS-like (MARCKSL)1은 cell proliferation을 증가시키는 것으로 알려져 있다. Zhao 등은 retrovirus를 이용한 MARCKSL의 과다 발현 시, 신장세포의 cell proliferation이 증가됨을 밝혔다[37]. Cluster 7의 발현 양상을 가지는 WNT1 inducible signaling pathway protein 2 (WISP2)는 cell growth에 관여한다고 알려져 있는데, WISP2 의 과다 발현은 종양 세포의 proliferation을 증가시킨다[27]. WISP2는 또한 adipogenesis을 저해하는 WNT/B-catenin pathway에 포함되므로 anti-adipogenesis로 작용할 것으로 예 상된다. colony stimulating factor 1 (CSF1)과 discoidin domain receptor family, member 2 (DDR2), leukemia inhibitory factor receptor (LIFR) 등은 cluster 8 의 발현 양상을 가지는 것으로 나타났는데, 이들은 cell proliferation을 증가시 키는 기능을 가진다. Kokkinaki 등은 CSF1 유전자가 손상된 마우스에서 백혈구의 수가 감소함을 보였다[16]. Tyrosine kinase receptor인, DDR2는 그 유전자를 마우스에서 제거하였 을 경우, 피부세포의 proliferation이 크게 감소되는 것으로 보 고되었다[22]. 또한, Derouet 등의 보고에 따르면, LIFR는 neuropoietin과의 상호작용을 통해 신경전구세포의 proliferation 을 증가시키는 기능을 가진다[9]. 언급한 유전자들 외에도 세 포의 증식, 세포주기 조절과 관련된 유전자들이 cluster 7 (cell division cycle and apoptosis regulator 1 (CCAR1), cysteine rich protein 61 (CYR61), SRY-box containing gene 9 (SOX9) 등)와 cluster 8 (checkpoint kinase 1 homolog (CHEK1), epiregulin (EREG), xpaired related homeobox 1 (EREG) 등)에 다수 포함되었다. 이러한 결과들은 SH21B가 지방세포형성 억 제 인자 및 세포증식 유도 인자들의 유전자 발현을 조절하여 지방세포형성을 억제함을 제시한다.

본 연구에서 언급된 많은 유전자들은 서로 복합적으로 작용 하여 지방세포형성을 억제하는 $\mathrm{SH} 21 \mathrm{~B}$ 의 분자 메커니즘에 포 함된다고 사료된다. 그러나, 그 중에서도 cluster 4 에 포함된 $\mathrm{PPAR} \gamma$ 와 $\mathrm{C} / \mathrm{EBPa}$ 는 지방세포형성을 조절하는 핵심 전사인 자이므로 $\mathrm{SH} 21 \mathrm{~B}$ 에 의해 억제되는 양상을 보이는 유전자들 중 가장 중요한 인자들로 생각된다[24]. 또한, $\mathrm{PPAR} \gamma$ 와 C/EBPa 의 발현과 단백질 활성을 억제한다고 알려진 $\beta$-catenin (cluster 7)과 CCND1 (cluster 8)은 지방세포형성을 억제하는 대표적인 인자로 알려져 있다. 따라서 $\beta$-catenin과 CCND1은 SH21B에 의해 상승되는 양상을 보이는 유전자들을 대표하는 가장 중요한 인자로 사료된다[4,13,20,35].

생체 내 대사에서 중요한 역할을 하는 지방세포형성은 많은 유전자의 발현 및 억제로 이루어지는 복잡한 과정이다. 전지 방세포에서는 지방세포형성 억제 조절자들과 세포증식 유도 인자들의 발현이 높게 발현되어 지방세포로의 분화를 억제한 다. 그러나 지방세포형성 유도 물질에 의해 분화가 시작되면 지방세포형성 억제 조절자들과 세포증식 유도 인자들의 발현 은 억제되고 반대로 지방세포형성 유도 조절자들과 세포증식 
억제 인자들의 발현이 증가한다[10]. 본 연구에서 SH21B는 세 포증식을 촉진하거나 지방세포형성을 억제하는 유전자의 발 현을 증가시키고, 이와 반대적인 기능을 가진 유전자의 발현 을 억제함으로써 전지방세포가 지방세포로 분화하는 것을 저 해하는 것으로 사료된다. 이후의 연구에서는 본 연구의 microarray 결과를 근거로 $\mathrm{SH} 21 \mathrm{~B}$ 에 의해 증가하는 양상을 보였던 $\beta$-catenin과 $\mathrm{CCND} 1$ 을 중심으로 지방세포형성 억제와 관련된 다고 알려진 WNT/ $\beta$-catenin pathway에 대한 연구가 진행될 계획이다. 이러한 분자생물학적 연구는 지방세포형성과 관련 하여 생물학적 원리를 밝히고, 더 나아가 향후 비만과 성인병 에 관련된 연구 및 치료에 적용될 중요하고 잠재성 있는 분자 표적(molecular target)이 될 것으로 예상된다.

\section{감사의 글}

본 연구는 보건복지가족부의 한의약선도기술개발사업 (B080020) 및 농촌진흥청의 바이오그린 21사업(20070301034-031)의 지원으로 이루어진 결과이며 이에 감사드립니다.

\section{References}

1. Ashida, H., T. Furuyashiki, H. Nagayasu, H. Bessho, H. Sakakibara, T. Hashimoto, and K. Kanazawa. 2004. Anti-obesity actions of green tea: possible involvements in modulation of the glucose uptake system and suppression of the adipogenesis-related transcription factors. Biofactors 22, 135-140.

2. Bai, F., X. H. Pei, T. Nishikawa, M. D. Smith, and Y. Xiong. 2007. p18Ink4c, but not p27Kip1, collaborates with Men1 to suppress neuroendocrine organ tumors. Mol. Cell Biol. 27, 1495-1504.

3. Bajenaru, M. L., J. Donahoe, T. Corral, K. M. Reilly, S. Brophy, A. Pellicer, and D. H. Gutmann. 2001. Neurofibromatosis 1 (NF1) heterozygosity results in a cell-autonomous growth advantage for astrocytes. Glia. 33, 314-323.

4. Bennett, C. N., S. E. Ross, K. A. Longo, L. Bajnok, N. Hemati, K. W. Johnson, S. D. Harrison, and O. A. MacDougald. 2002. Regulation of Wnt signaling during adipogenesis. J. Biol. Chem 277, 30998-31004.

5. Cadigan, K. M. and Y. I. Liu. 2006. Wnt signaling: complexity at the surface. J. Cell Sci. 119, 395-402.

6. Cao, Y., G. Bonizzi, T. N. Seagroves, F. R. Greten, R. Johnson, E. V. Schmidt, and M. Karin. 2001. IKKalpha provides an essential link between RANK signaling and cyclin D1 expression during mammary gland development. Cell 107, 763-775.

7. Corazzari, M., P. E. Lovat, S. Oliverio, F. Di Sano, R. P. Donnorso, C. P. Redfern, and M. Piacentini. 2005. Fenretinide: a p53-independent way to kill cancer cells. Biochem Biophys. Res. Commun. 331, 810-815.
8. Darlington, G. J., S. E. Ross, and O. A. MacDougald. 1998. The role of C/EBP genes in adipocyte differentiation. J. Biol. Chem 273, 30057-30060.

9. Derouet, D., F. Rousseau, F. Alfonsi, J. Froger, J. Hermann, F. Barbier, D. Perret, C. Diveu, C. Guillet, L. Preisser, A. Dumont, M. Barbado, A. Morel, O. deLapeyriere, H. Gascan, and S. Chevalier. 2004. Neuropoietin, a new IL-6-related cytokine signaling through the ciliary neurotrophic factor receptor. Proc. Natl. Acad Sci. USA 101, 4827-4832.

10. Fajas, L. 2003. Adipogenesis: a cross-talk between cell proliferation and cell differentiation. Ann. Med. 35, 79-85.

11. Fajas, L., K. Schoonjans, L. Gelman, J. B. Kim, J. Najib, G. Martin, J. C. Fruchart, M. Briggs, B. M. Spiegelman, and J. Auwerx. 1999. Regulation of peroxisome proliferator-activated receptor gamma expression by adipocyte differentiation and determination factor 1 /sterol regulatory element binding protein 1: implications for adipocyte differentiation and metabolism. Mol. Cell. Biol. 19, 5495-5503.

12. Freytag, S. O., D. L. Paielli, and J. D. Gilbert. 1994. Ectopic expression of the CCAAT/enhancer-binding protein alpha promotes the adipogenic program in a variety of mouse fibroblastic cells. Genes Dev. 8, 1654-1663.

13. Fu, M., M. Rao, T. Bouras, C. Wang, K. Wu, X. Zhang, Z. Li, T. P. Yao, and R. G. Pestell. 2005. Cyclin D1 inhibits peroxisome proliferator-activated receptor gamma-mediated adipogenesis through histone deacetylase recruitment. J. Biol. Chem 280, 16934-16941.

14. Guo, X. and K. Liao. 2000. Analysis of gene expression profile during 3T3-L1 preadipocyte differentiation. Gene 251, 45-53.

15. Hulit, J., C. Wang, Z. Li, C. Albanese, M. Rao, D. Di Vizio, S. Shah, S. W. Byers, R. Mahmood, L. H. Augenlicht, R. Russell, and R. G. Pestell. 2004. Cyclin D1 genetic heterozygosity regulates colonic epithelial cell differentiation and tumor number in ApcMin mice. Mol. Cell Bid. 24, 7598-7611.

16. Kokkinaki, M., T. L. Lee, Z. He, J. Jiang, N. Golestaneh, M. C. Hofmann, W. Y. Chan, and M. Dym. 2009. The molecular signature of spermatogonial stem/progenitor cells in the 6-day-old mouse testis. Biol. Reprod 80, 707-717.

17. Lee, H., R. Kang, Y. Hahn, Y. Yang, S. S. Kim, S. H. Cho, S. I. Chung, and Y. Yoon. 2009. Antiobesity effect of baicalin involves the modulations of proadipogenic and antiadipogenic regulators of the adipogenesis pathway. Phytother. Res. 23, 1615-1623.

18. Lee, H., R. Kang, and Y. Yoon. 2009. SH21B, an anti-obesity herbal composition, inhibits fat accumulation in 3T3-L1 adipocytes and high fat diet-induced obese mice through the modulation of the adipogenesis pathway. J. Ethnopharmacol. DOI: 10.1016/j.jep.2009.12.002.

19. Liu, A. X., N. Rane, J. P. Liu, and G. C. Prendergast. 2001. RhoB is dispensable for mouse development, but it modifies susceptibility to tumor formation as well as cell adhesion and growth factor signaling in transformed cells. Mol. Cell Biol. 21, 6906-6912.

20. Liu, J., H. Wang, Y. Zuo, and S. R. Farmer. 2006. Functional interaction between peroxisome proliferator-activated re- 
ceptor gamma and beta-catenin. Mol. Cell Biol. 26, 5827-5837.

21. Lockhart, D. J., H. Dong, M. C. Byrne, M. T. Follettie, M. V. Gallo, M. S. Chee, M. Mittmann, C. Wang, M. Kobayashi, H. Horton, and E. L. Brown. 1996. Expression monitoring by hybridization to high-density oligonucleotide arrays. Nat. Biotechnol. 14, 1675-1680.

22. Olaso, E., J. P. Labrador, L. Wang, K. Ikeda, F. J. Eng, R. Klein, D. H. Lovett, H. C. Lin, and S. L. Friedman. 2002. Discoidin domain receptor 2 regulates fibroblast proliferation and migration through the extracellular matrix in association with transcriptional activation of matrix metalloproteinase-2. J. Biol. Chem 277, 3606-3613.

23. Perseghin, G., K. Petersen, and G. I. Shulman. 2003. Cellular mechanism of insulin resistance: potential links with inflammation. Int. J. Obes. Relat. Metab. Disord 27 Suppl 3, S6-11.

24. Rosen, E. D. and O. A. MacDougald. 2006. Adipocyte differentiation from the inside out. Nat Rev. Mol. Cell Biol. 7, 885-896.

25. Ross, S. E., N. Hemati, K. A. Longo, C. N. Bennett, P. C. Lucas, R. L. Erickson, and O. A. MacDougald. 2000. Inhibition of adipogenesis by Wnt signaling. Science 289, 950-953.

26. Sage, J., A. L. Miller, P. A. Perez-Mancera, J. M. Wysocki, and T. Jacks. 2003. Acute mutation of retinoblastoma gene function is sufficient for cell cycle re-entry. Nature 424, 223-228.

27. Saxena, N., S. Banerjee, K. Sengupta, M. N. Zoubine, and S. K. Banerjee. 2001. Differential expression of WISP-1 and WISP-2 genes in normal and transformed human breast cell lines. Mol. Cell Biochem 228, 99-104.

28. Schoonjans, K., J. Peinado-Onsurbe, A. M. Lefebvre, R. A. Heyman, M. Briggs, S. Deeb, B. Staels, and J. Auwerx. 1996. PPARalpha and PPARgamma activators direct a distinct tissue-specific transcriptional response via a PPRE in the lipoprotein lipase gene. $E M B O J .15,5336-5348$.

29. Sethi, J. K. and A. J. Vidal-Puig. 2007. Thematic review series: adipocyte biology. Adipose tissue function and plasticity orchestrate nutritional adaptation. J. Lipid Res. 48,
1253-1262.

30. Shang, W., Y. Yang, B. Jiang, H. Jin, L. Zhou, S. Liu, and M. Chen. 2007. Ginsenoside Rb1 promotes adipogenesis in 3T3-L1 cells by enhancing PPARgamma2 and C/EBPalpha gene expression. Life Sci. 80, 618-625.

31. Shang, W., Y. Yang, L. Zhou, B. Jiang, H. Jin, and M. Chen. 2008. Ginsenoside $\mathrm{Rb} 1$ stimulates glucose uptake through insulin-like signaling pathway in 3T3-L1 adipocytes. J. Endocrinol. 198, 561-569.

32. Shimomura, I., R. E. Hammer, J. A. Richardson, S. Ikemoto, Y. Bashmakov, J. L. Goldstein, and M. S. Brown. 1998. Insulin resistance and diabetes mellitus in transgenic mice expressing nuclear SREBP-1c in adipose tissue: model for congenital generalized lipodystrophy. Genes Dev. 12, 3182-3194.

33. Tang, Q. Q., T. C. Otto, and M. D. Lane. 2003. Mitotic clonal expansion: a synchronous process required for adipogenesis. Proc. Natl. Acad Sci. USA 100, 44-49.

34. Tontonoz, P., E. Hu, and B. M. Spiegelman. 1994. Stimulation of adipogenesis in fibroblasts by PPAR gamma 2, a lipid-activated transcription factor. Cell 79, 1147-1156.

35. Wang, C., N. Pattabiraman, J. N. Zhou, M. Fu, T. Sakamaki, C. Albanese, Z. Li, K. Wu, J. Hulit, P. Neumeister, P. M. Novikoff, M. Brownlee, P. E. Scherer, J. G. Jones, K. D. Whitney, L. A. Donehower, E. L. Harris, T. Rohan, D. C. Johns, and R. G. Pestell. 2003. Cyclin D1 repression of peroxisome proliferator-activated receptor gamma expression and transactivation. Mol. Cell Biol. 23, 6159-6173.

36. Zeeberg, B. R., W. Feng, G. Wang, M. D. Wang, A. T. Fojo, M. Sunshine, S. Narasimhan, D. W. Kane, W. C. Reinhold, S. Lababidi, K. J. Bussey, J. Riss, J. C. Barrett, and J. N. Weinstein. 2003. GoMiner: a resource for biological interpretation of genomic and proteomic data. Genome Biol. 4, R28.

37. Zhao, J., T. Izumi, K. Nunomura, S. Satoh, and S. Watanabe. 2007. MARCKS-like protein, a membrane protein identified for its expression in developing neural retina, plays a role in regulating retinal cell proliferation. Biochem J. 408, 51-59. 


\section{초록 : 생약복합물의 지방세포형성억제 기전규명을 위한 전사체 분석}

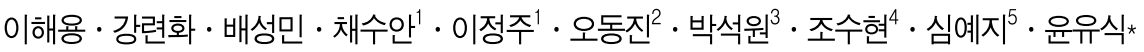

(중앙대학교 의과대학 미생물학교실, ${ }^{1}$ 소아과학교실, ${ }^{2}$ 내과학교실, ${ }^{3}$ 방사선종양학과, ${ }^{4}$ 가정의학과, ${ }^{5}$ 서울여자 대학교 교양학부)

생약복합물인 $\mathrm{SH} 21 \mathrm{~B}$ 는 황금(Scutellaria baicalensis Georgi), 행인(Prunus armeniaca Maxim), 마황(Ephedra sinica Stapf), 석창포(Acorus gramineus Soland), 포황(Typha orientalis Presl), 원지(Polygala tenuifolia Willd), 하엽 (Nelumbo nucifera Gaertner)의 혼합(비율 3:3:3:3:3:2:2)으로 이루어졌다. SH21B는 예로부터 한의학에서 비만의 치 료에 사용되어 왔으나 자세한 분자적 메커니즘과 효능에 대한 연구는 이루어지지 않았다. 본 연구진은 선행연구 를 통해 SH21B가 지방세포의 분화에서 adipogenesis (지방세포형성)와 관련된 유전자를 조절하여 중성지방의 축 적을 억제함을 밝혔다. 본 연구에서는, microarray 기술을 이용하여 adipogenesis의 in vitro 모델인, 3T3-L1 세포 에서 $\mathrm{SH} 21 \mathrm{~B}$ 에 의한 지방세포형성 억제의 분자적 기작을 보다 상세하게 연구하고자 하였다. 전지방세포, 분화된 세포 그리고 $\mathrm{SH} 21 \mathrm{~B}$ 에 의해 분화가 억제된 세포의 각각의 유전자 발현을 분석하기 위해 각 시료들에서 total $\mathrm{RNA}$ 를 분리하여 $\mathrm{cDNA}$ 를 합성한 후 microarray에 적용시켰다. 그 결과, 각각의 시료들의 비교에서 2배 이상의 유의한 발현 변화를 가지는 2,568개의 유전자를 확보하였다. 이 유전자들에 대해 Hierarchical clustering과 K-means clustering 분석을 진행하였고 서로 다른 양상을 가지는 9개의 군집(cluster)들을 분류하였다. 그 중, $\mathrm{SH} 21 \mathrm{~B}$ 의 첨가에 의해 뚜렷하게 감소(cluster 4, cluster 6 및 cluster 9)하거나 반대로 뚜렷하게 증가(cluster 7와 cluster 8)하는 양상을 보이는 군집들을 따로 선별하여 그 군집들에 포함되어 있는 유전자들을 분석하였다. 선택 된 5개의 군집에는 지방세포형성과 세포증식에 관련된 유전자가 다수 포함되어 있었다. Cluster 4, cluster 6 그리 고 cluster 9에는 peroxisome proliferator activated receptor gamma $\gamma$ (PPAR $\gamma$ ), CCAAT/enhancer binding protein a $(\mathrm{C} / \mathrm{EBPa})$, sterol regulatory element binding transcription factor 1 (SREBF1), adiponectin (ADIPOQ), fatty acid synthase (FASN), lipoprotein lipase (LPL) 등의 지방세포형성 유도 및 관련 인자와 B-cell leukemia/lymphoma6 (BCL6), retinoblastoma 1 (RB1), cyclin-dependent kinase inhibitor 2C (CDKN2c), ras homolog gene family, member B (RHOB) 등의 많은 세포증식 억제 유전자가 포함되었다. 이와는 반대로, cluster 7과 cluster 8에는 $\beta$-catenin, cyclin D1 (CCND1), WNT1 inducible signaling pathway protein 2 (WISP2) 등과 같은 지방 세포형성 억제 조절자와 MARCKS-like1 (MARCKSL1), colony stimulating factor 1 (CSF1), discoidin domain receptor family, member 2 (DDR2), leukemia inhibitory factor receptor (LIFR) 등의 세포증식을 유도하는 조절자 가 다수 포함되었다. 결론적으로, 이러한 결과들은 SH21B가 지방세포형성과 관련된 조절자 및 세포증식과 관련 된 조절자들의 유전자 발현을 조절하여 지방세포형성을 억제함을 제시한다. 